\title{
Duration of Residence in the Rental Housing Market
}

by

Yongheng Deng*, Stuart A. Gabriel*, and Frank E. Nothaft**

January 2002

*Lusk Center for Real Estate, School of Policy, Planning and Development and Marshall School of Business, University of Southern California, 331 Lewis Hall, Los Angeles, California, 90089-0626.

**Housing Economics and Financial Research Department, Freddie Mac, 8200 Jones Branch Drive, McLean, Virginia 22102-3107.

Corresponding Author: Yongheng Deng, Lusk Center for Real Estate, University of Southern California, 650 Childs Way, RGL 328, Los Angeles, CA 90089-0626, E-mail: ydeng@usc.edu.

The authors further wish to thank Frank Ptacek and Steve Henderson of the Bureau of Labor Statistics for many discussions regarding the CPI housing sample, and Stephen Cauley, Greg Schwann, and an anonymous referee for helpful comments. The authors are grateful to Lihong Yang for excellent research assistance. An earlier version was presented at the American Real Estate and Urban Economics Annual Meetings 2001, the University of Southern California Lusk Research Symposium 2001, and the Cambridge-Maastricht Real Estate Research Symposium 2001. The views expressed are those of the authors and do not necessarily reflect those of Freddie Mac or the Bureau of Labor Statistics. 


\title{
Duration of Residence in the Rental Housing Market
}

\author{
Yongheng Deng, Stuart A. Gabriel, and Frank E. Nothaft \\ University of Southern California and Freddie Mac
}

\begin{abstract}
This paper estimates a proportional hazard model of duration of residence in rental housing. The study employs unique data from the BLS-CPI housing sample to construct the duration of rental occupancy for metropolitan areas over the 1987-1998 period. American Housing Survey and other metropolitan economic data are used to proxy time-varying covariates of duration of residence. The paper employs an innovative semi-parametric estimation approach for group duration analysis of the proportional hazard model, as originally proposed by Ryu (1994) and then modified by Deng [(1995), (1997)].

Results of the analysis indicate that the duration of residence in rental housing varies significantly across individual units and market segments. In fact, the duration of residence is highly time dependent, given significant intertemporal variation in many of the housing and market covariates. The paper provides evidence of high tenant turnover rates at about 3 years of residence. However, the turnover hazard curve depends as well on market conditions and housing policy. For example, imposition of rent control can shift the peak of the tenant turnover hazard curve to the left. Research findings further indicate that median housing costs, public housing share of the rental stock, poverty rate, and African-American and Hispanic share of tenant households are among those factors that positively affect tenant turnover hazard rates and hence are negatively related to tenant residence duration. Elevator buildings, unemployment rate, population growth and central city share of the rental stock negatively affect tenant turnover hazard rates and hence are positively related with tenant residence duration. Further, the estimated pattern of duration of residence was shown to vary substantially across 33 large metropolitan markets.

Simulation results further indicate the sensitivity of duration of residence to housing locational and structural characteristics. For example, findings for New York City indicate that increased geographic dispersion of rental housing, as reflected in a reduction in the share of rental stock in the central city to national average levels, would serve to boost cumulative tenant turnover rates by 12 percent by the end of year three of the rental lease. Similarly, simulated reduction in the density of rental housing, as reflected in downward adjustment in the share of NYC buildings with seven or more stories to that of the national average level, would serve to increase cumulative tenant turnover rates by 13 percent. The research provides new evidence as regards tenant and market characteristics that determine the duration of residency. Clearly, an improved understanding thereof offers new insights as regards fluctuations in tenant turnover, building occupancy, and rent flows, as well as new confidence in pro forma assumptions critical to rental housing development.
\end{abstract}




\section{Introduction}

Recent years have witnessed ongoing research and policy debate as regards cyclical fluctuations in rental housing markets. In many cases, market fluctuations are not well predicted, suggesting relatively high levels of risk as regards anticipated returns to investment in rental property. Accordingly, investors, regulators and analysts alike have focused on improved understanding of the fundamentals of rental housing market dynamics. To that end, academic analyses have assessed the role of equilibrium vacancy rates in determination of the price adjustment mechanism for rental housing [see, for example, Blank and Winnick (1953), Rosen and Smith (1983), Gabriel and Nothaft (1988), Muller (1991), Wheaton and Torto (1994), and Belsky and Goodman (1996)]. Those models suggest the importance of deviations between observed and equilibrium vacancy rates in the determination of rent fluctuations. More recently, Gabriel and Nothaft (2001) provided new estimation and assessment of rental vacancy incidence and duration and indicated the importance of those measures to an improved understanding of the rental price adjustment mechanism. That aside, little is known about duration dependence in rental housing, particularly as regards duration of occupancy.

The limited literature on duration of residence in rental housing owes in part to lack of appropriate data. Indeed, the Bureau of Labor Statistics' (BLS) Consumer Price Index (CPI) housing sample employed in this analysis is expansive in both geographic and intertemporal detail and appears uniquely qualified for such an inquiry. Yet that data has been utilized only in one prior study of incidence and duration of rental vacancies [Gabriel and Nothaft (2001)]. Prior analyses rely on limited data resources and/or more restrictive models and specifications [see, for example, Guasch and Marshall (1987), Rosenthal (1988) and Gronberg and Reed (1992)].

The literature does contain a few analyses of duration dependence in the housing market. A number of authors, including Belkin et al (1976), Zuehlke (1987), Haurin (1988), and Kluger and Miller (1990) have modeled time-on-market and its hazard rate. Other studies have focused on the duration of rental housing vacancies [see Sternberg (1994) and Gabriel and Nothaft (2001)]. Sternberg (1994) modeled the probability of exiting vacancy status; that analysis employed a restrictive constant hazard framework, which implies a 
constant vacancy rate over time. Such a restriction is apparently inappropriate in the rental housing markets. The focus of the Gabriel and Nothaft (2001) analysis was decomposition of rental vacancies into their incidence and duration components, and then evaluating the decomposed incidence and duration separately, particularly as regards estimation of equilibrium vacancy rates. Data structure did not permit focus on the time-varying nature of the duration dependence in rental housing.

This paper presents estimates of a proportional hazard model for duration of residence in rental housing. The hazard rate for this model is the conditional probability that residence in a rental unit is terminated at time $t$, given that it was occupied prior to $t$. Thus, the survivor function summarizes the conditional probability of continued occupancy over time. To estimate the proportional hazard function of residence duration, the study employs unique and particularly rich data from the CPI housing sample to construct the duration of residence in rental housing market. That data set is combined with information from the American Housing Survey and other metropolitan economic information in order to proxy timevarying covariates of duration of residence. Accordingly, the paper evaluates both time-invariant as well as time-varying determinants of duration of rental housing occupancy. In so doing, the paper employs an innovative semi-parametric estimation approach for group duration analysis of the proportional hazard model, as originally proposed by Ryu (1994) and then modified by Deng [(1995), (1997)].

Results of the analysis indicate that the duration of residence in rental housing varies significantly across individual units and market segments. In fact, the duration of residence is highly time dependent, given significant intertemporal variation in many of the housing and market covariates. For example, during periods of relatively low mortgage interest rates and/or increasing house prices, duration of rental occupancy is reduced. The paper provides evidence of high tenant turnover rates at about 3 years of residence. However, the turnover hazard curve depends as well on market conditions and housing policy. For example, imposition of rent control can shift the peak of the tenant turnover hazard curve to the left. Furthermore, consumers' expectations regarding housing supply and demand may also change the shape of the duration curve. Research findings further indicate that median housing costs, public housing share of the rental stock, poverty rate, and African-American and Hispanic share of tenant households are among those 
factors that positively affect tenant turnover hazard rates and hence are negatively related to tenant residence duration. Elevator buildings, unemployment rate, population growth and central city share of the rental stock negatively affect tenant turnover hazard rates and hence are positively related with tenant residence duration. Further, the estimated pattern of duration of residence was shown to vary substantially across 33 large metropolitan markets.

Simulation results further indicate the sensitivity of duration of residence to housing locational and structural characteristics. For example, findings for New York City indicate that increased intrametropolitan dispersion of rental housing, as reflected in reduction in the share of rental stock in the central city to national average levels, would serve to boost cumulative tenant turnover rates by 12 percent by the end of year three of the rental lease. Similarly, simulated reduction in the density of rental housing, as reflected in downward adjustment in the share of NYC buildings with seven or more stories to that of the national average level, would serve to increase cumulative tenant turnover rates by 13 percent. These results provide new evidence as regards tenant and market characteristics that determine the duration of residency. Clearly, an improved understanding thereof offers new insights as regards fluctuations in tenant turnover, building occupancy, and rent flows, as well as new confidence in pro forma assumptions critical to rental housing development.

The plan of the paper is as follows. Section II discusses the proportional hazard model as well as the semi-parametric estimation approach used in this study. Section III describes the construction of the housing unit event-history sample based on data from the CPI housing sample, the American Housing Survey, and other regional economic information. Section IV discusses model specification and reports on econometric evaluation of the duration of rental housing occupancy. Finally, section V discusses conclusions and policy implications of the research. 


\section{The Model}

The proportional hazard model introduced by Cox (1972) provides a coherent framework in which to analyze the duration of residence in rental housing. The hazard function in this model is defined as the product of a baseline hazard function and a set of proportional factors, such that

$$
h(\tau, X)=h_{0}(\tau)[\exp (X(\tau) \beta)]
$$

where $h_{0}(\tau)$ is the baseline hazard function, $X(\tau)$ is a vector of proportional factors. The baseline hazard function describes the overall shape of the hazard rate for termination of rental housing occupancy over time, with the proportional factors capturing time-constant as well as time-varying covariate effects across individual rental housing units. These covariates include housing structural characteristics as well as other economic and demographic determinants of duration of residence that vary over time.

The proportional hazard model evaluates the probability of termination of rental housing occupancy conditional on occupancy of the unit to that point in time. Therefore, the model not only evaluates the determinants of occupancy termination at the time of termination, but also analyzes tenant behavior over the entire event history of rental unit occupancy. In other words, the model not only evaluates the determinants of current termination of rental housing occupancy, but also analyzes why the tenant did not terminate occupancy in prior periods.

Cox developed a partial likelihood estimation technique that can estimate the covariate effects without specifying the baseline hazard function (see Cox (1975), Kalbfleisch and Prentice (1980), and Cox and Oakes (1984) for a detailed discussion). The original Cox proportional hazard model was designed for applications in continuous time. However, economic data are typically collected in discrete time intervals. For example, the CPI housing survey is conducted in an interval of six-month periods. The housing survey and economic data collected in discrete time intervals make it difficult to apply the Cox partial likelihood approach to estimate the proportional hazard model, because more than one failure (termination) may be reported within the same interval and the Cox partial likelihood technique cannot 
identify failure observations with ties. In addition, housing market analysts often are interested in the changing pattern of the baseline hazard over time, as it may reveal important determinants of rental housing market activity. Therefore, it is neither appropriate nor desirable to ignore the baseline hazard function, as implied by the Cox partial likelihood technique.

In this study, we adopt a semi-parametric estimation approach for group duration analysis of the proportional hazard model proposed by Ryu (1994) and modified by Deng [(1995), (1997)]. In this context, we define $\tau \in R^{+}$as a duration variable. Let $\tau_{t}(t=1,2, \ldots T)$ be the discrete time intervals that partition the support of $\tau$.

Let $S_{1}$ be the probability that $\tau$ survives the discrete time period 1 , let $S_{2}$ be the conditional probability that $\tau$ survives the discrete time period 2 conditional on that it has already survived period 1 , and $S_{t}$ be the conditional probability that $\tau$ survives the discrete time period $t$ conditional on that it has already survived period $t-1$, where $t=1,2, \ldots, T$. The proportional hazard function in equation (1) can be expressed into follow discrete survivor function, such that

$$
S_{1}=\exp \left[-\int_{0}^{1} h(\tau, x) d \tau\right]=\exp \left[-\exp \left(\gamma_{1}+x \beta\right)\right]
$$

and

$$
S_{t}=\exp \left[-\int_{t-1}^{t} h(\tau, x) d \tau\right]=\exp \left[-\exp \left(\gamma_{t}+x \beta\right)\right]
$$

where $\gamma_{t}=\log \left[\int_{t-1}^{t} h_{0}(\tau) d \tau\right]$ is a $\log$ value of flexible baseline hazard, which may be estimated nonparametrically following Han and Hauseman (1990).

The left-hand side of equations (2) and (3), S's, are typically not directly observable in micro data. We can, however, use the 'local smoothing' technique developed in the literature on non-parametric methods to estimate individual survival functions based on the empirical distribution of the survival functions. We partition the survival data sample into $K$ distinct synthetic pools; the $k$ th pool contains $M_{k}$ 
observations, and $M_{1}+M_{2}+\ldots+M_{k}=N$, where $N$ is the total sample size. For each pool, we estimate the survival probability in period t such that $\hat{S}_{k, t}=n_{k, t} / n_{k, t-1}$, where $n_{k, t}$ is the number of observations in the $k$ th pool that survive period $t$. The discrete proportional hazard model can therefore be estimated in following regression:

$$
\log \left[-\log \left(\hat{S}_{i, k, t}\right)\right]=\gamma_{t}+x_{i, k, t} \beta
$$

Selection of the value of the smoothing parameter is analogous to parameter selection in nonparametric estimation. $M_{k}$ is chosen to reduce the noise as well as to keep the approximation error (bias) low. Noise will be reduced by letting $M_{k}$ approach infinity as a function of the sample size. Approximation error will be eliminated if the neighborhood around $S_{k}$ shrinks asymptotically to zero. Unfortunately, these prescriptions conflict. A standard proposition in the non-parametric literature suggests that as $M_{k} \rightarrow \infty, M_{k} / N \rightarrow 0$, and $N \rightarrow \infty$, a balance between these two goals can be achieved in an asymptotic sense by setting $M_{k} \sim N^{4 / 5}$. A consequence is that the mean squared error itself converges to zero at a rate of $M_{k}^{-1} \sim N^{-(4 / 5)}$. In other words, the rate of convergence for this nonparametric estimation is $N^{-(2 / 5)} \cdot 1$

\section{The Data}

\subsection{The CPI Housing Sample}

The CPI housing sample is the source of information on changes in the price of housing services for the CPI's two principle shelter indexes--the residential rent index and the owners' equivalent rent index. The CPI housing sample is a stratified cluster sample of approximately 40,000 rental units and 20,000 owner

\footnotetext{
${ }^{1}$ See Härdle (1990), section 3.2 for a discussion.
} 
units. $^{2}$ The overall sample is divided into six panels with rental units surveyed every six months, resulting in two data collections per year per apartment in the sample. The sample is comprised of 1,077,703 survey records. ${ }^{3}$

In any given month, the BLS field representatives visit that month's housing panel and gather information on, among other items, the tenure status of the dwelling unit (owner or rental), current occupancy status (vacant or occupied), duration in months of occupancy (if occupied), and, for rental units, the rent. The resulting dataset is well suited to the analysis of the duration of residence in rental housing, given its high sampling frequency and the detail of information collected over the between-survey period. The analysis undertaken in this paper uses the CPI housing sample over the January 1987 to December 1998 period.

The survey data include information reporting current occupancy status of the housing unit, the length of occupant residency, whether the unit is currently renter occupied or owner occupied as well as the tenure of the unit at initiation, the building structure type (which include the following seven categories: single-family detached, single-family semi-detached, single-family attached, mobile home/trailer, multi-unit with elevator, multi-unit without elevator, and other), ${ }^{4}$ the metropolitan area where the housing unit is located, and the month and year in which the data were collected.

\subsection{The American Housing Survey Sample}

The American Housing Survey (AHS) sample includes metropolitan area level housing market information for the 1984-1998 period. There are 44 MSAs represented, surveyed approximately every fourth year. The AHS provides a rich set of housing market and population indicators, including total rental housing stock, housing stock by race/ethnicity, age, poverty status, and recent mover status of occupants, and

2 The CPI housing panels used in this paper were initiated in January 1987 and terminated in December 1998. For additional information, see U.S. Department of Labor (1992). In order to ensure that the CPI housing sample remains current, the BLS augments the dataset based on building permit data obtained from the Census Bureau and from canvassing of areas not requiring building permits.

${ }^{3}$ Thus there is a "January-July" rental panel which is surveyed in each of those months, a "February-August" panel, a "March-September" panel, and so on. Note, however, that only half of the owner units are surveyed in each of the panel survey months, resulting in the collection of owner data only once during the year (e.g., half of the owner units in the "January-July" panel are surveyed in January and the other half in July). 
distribution of the housing stock by rent control status, public housing status, location (central city), number of bedrooms, number of stories, and median (MSA) housing costs (see U.S. Department of Commerce, various dates).

\subsection{Other MSA Economic Data}

We also include MSA-level economic indicators such as nonfarm payroll employment, unemployment rate, single-family and multifamily building permits, income and population. These data were tabulated by the Census Bureau and the BLS and provided to us by Economy.com.

\subsection{The Housing Units Event History Sample}

Our empirical analysis is based on a housing units event-history sample constructed from the CPI housing sample, the AHS housing sample and the regional economic data files. We use linear techniques to extrapolate the regional economic and AHS housing data to semi-annual frequency, so that they can be matched to the CPI sample of rental housing units. ${ }^{5}$ The sample contains the event history of individual housing units until the termination of the rental occupancy. This rich data set provides a unique opportunity to conduct a time-varying analysis of the factors determining the duration of residence in rental housing. The final sample used in the duration analysis contains 21,191 units with 301,467 eventhistory records in 33 MSAs.

For each housing unit event-history record, a tenant occupancy duration variable is constructed based on the following criteria: at the time of survey, if the respondent reports that the housing unit is occupied and the tenant has lived in the current unit for more than six months, then the duration increases by one period. However, if the surveyor finds either that the unit is vacant at the time of the survey, or that the tenant has been living in the unit for less than or equal to six months (which implies that a spell of vacancy has occurred), then the previous tenant's occupancy duration is terminated. In other words,

\footnotetext{
${ }^{4}$ Other includes mixed commercial and residential structures, such as an apartment above a store front or professional office, and apartments in or above garages. Mobile homes that are not on permanent foundations or blocks, and houseboats that are not permanently moored are excluded from the survey.

${ }^{5}$ The CPI survey data with missing building structure types were also excluded.
} 
duration equal to one (period) implies that the unit has been continuously occupied for more than six months but less than twelve months. ${ }^{6}$ Duration equal to two (periods) implies that the unit has been continuously occupied for more than twelve months but less than eighteen months, and so forth. Because the housing-unit panels are surveyed semi-annually over 12 years, the maximum value for duration is 23 (periods). ${ }^{7}$

Table I compares duration of residence among rental structure types for the BLS housing sample and the 1997 American Housing Survey. Despite some differences in survey design and time frame, findings are roughly consistent. AHS results suggest that some 36 percent of the occupants of rental housing had moved during the prior year; in comparison, 45 percent of units surveyed by the BLS had been occupied for less than one year. Among structure types, among single-family attached units, 46 percent of BLS units surveyed over the 1987-1998 period had been occupied for less than one year. Among single-family attached housing units surveyed by the AHS in 1997, 41 percent of the occupants had moved during the prior year. Similar values were evidenced among other structure types.

Table II provides a comparison of duration of residence in rental housing between the BLS sample and the 1990 Census of Population and Housing. As is evidenced, results confirm a close correspondence between our computed 1987-1998 BLS duration of residence of less than one year (45 percent) and the portion of tenants that moved into rental housing during the 1989-1990 period (42 percent). In general, results reported in Table II indicated a relatively close correspondence in duration of residence for short- and mid-term duration; however, in the case of very long-term duration of residence

\footnotetext{
${ }^{6}$ Because the survey is conducted every six months, this data set does not permit us to identify occupancy of less than six months.

${ }^{7}$ One feature of the rental housing occupancy duration data is the possibility of left censoring. Left censoring occurs when the residential occupancy starts prior to the starting point of the sample. Concerns regarding left censoring of sample data have been well documented in the labor economics literature. Here we assume that the mechanisms associated with the left censoring of our housing occupancy duration data are random and therefore will not bias our estimates.
} 
in rental housing, computations of the data sets diverge, with substantially higher levels of ten-or-more years of occupancy indicated in the Census.

Exhibit I illustrates the distribution of duration residence in rental housing for units in the BLS sample with occupancy greater than six months. ${ }^{8}$ For the overall sample, close to five percent have duration equal to one (more than six months but less than 12 months), whereas ten percent of sampled units have duration equal to five (upwards to 3 years). The Exhibit II reports the distribution of residency duration in rental housing by building structure type. Results indicate higher rates of turnover for singlefamily housing and mobile homes during the first two to three years of observation; thereafter, little difference in duration of residence was evidenced among structure types. Exhibit III displays the distribution of residency duration in rental housing for selected sample MSAs. As is evidenced in the chart, there exist considerable variation among cities in pattern of residence duration. Such is particularly evident in comparison of San Francisco with such east coast cities as Philadelphia, New York, and Pittsburgh.

\subsection{Computation of Empirical Survival Rates}

Following the discussion in Section II, we partitioned our housing sample into over 5,500 synthetic pools (by 33 MSAs, 7 building structure types, and 24 starting periods of rental housing occupancy). For each synthetic pool, we computed empirical survival rates such that $\hat{S}_{k, t}=n_{k, t} / n_{k, t-1}, t=1,2, \ldots, T$, where $n_{k, t}$ is the number of observations in the $k$ th pool with computed rental housing occupancy duration greater or equal to $t$. We then assign empirical survival rates to each observation in the rental housing event-history sample (in accordance to the pool in which the eventhistory record is located).

\footnotetext{
${ }^{8}$ Because the survival rate for duration equal to zero (that it, occupancy of less than six months) is not well defined in the discrete data set, the event history records with duration equal to zero were excluded in the statistical analysis. However, these records were included in the Table I and Table II calculations for comparison with the American Housing Survey and the decennial census distributions.
} 
Table III reports the means and standard deviations of the computed duration and survival rates in the sample. It also reports means and standard deviations of the covariates (the proportional factors, $X(\tau))$ of the proportional hazard model. Since many of the covariates are time varying, we report the statistics from the entire event-history sample as well as at the time when the rental housing occupancy terminates. As is evident, the summary statistics for the covariates at termination and event history samples are highly similar. The rental-housing sample is relatively diverse; some 4 percent of units are comprised of 4-or-more bedrooms and some 6 percent of units are buildings with 7-or-more stories. Public housing and rent-controlled units comprise about 6 and 4 percent of the sample, respectively. Some 43 percent of surveyed units are located in the central city.

\section{Empirical Estimation and Results}

This section reports on econometric evaluation of duration of residence in rental housing based on discrete proportional hazard model specified in equations (1) to (4). As suggested above, controls for renter population and rental housing stock characteristics were obtained from the metropolitan area files of the American Housing Survey, whereas local market and economic indicators were obtained from Economy.com. Table IV reports on the estimation of two proportional hazard models of rental housing duration of residence. Model I is specified with a common baseline hazard function for the entire sample, but includes MSA-specific fixed effects together with a group of covariates that serve as proportional factors to adjust the survival curve. Model II is specified with 33 MSA-specific baseline hazard functions together with a group of covariates. All models are estimated using OLS approach. The baseline hazard functions are estimated non-parametrically following Han and Hauseman (1990). ${ }^{9}$

\footnotetext{
${ }^{9}$ A third model was estimated that contained no MSA fixed effects nor variation in MSA baseline hazards; this model fit the data less well (R-square equal to 0.4890). The structure type variables had the same sign and rank ordering as in Models 1 and 2. Some of the tenant demographic and rental stock characteristics had different signs and larger coefficients, indicating that they were capturing various MSA effects; for example, the rent control variable had an estimated coefficient of -2.9 and a t-statistic of 178.9.
} 
As suggested in estimates from Model I, our computations indicate significant cross-city and intertemporal variation in duration of rental occupancy. In general, the MSA fixed-effects, housing market and economic characteristics are statistically significant; overall, the models explain about two-thirds of the variation in the duration of residence in rental housing. Estimates from both Model I and Model II support earlier findings by Gabriel and Nothaft (2001).

As evidenced in Table IV, rent levels have a statistically significant and positive impact on the hazard rate of occupancy, or in other words, have a negative effect on duration of rental occupancy. Rent levels are represented by tenants' median housing costs for each metropolitan area as computed in the American Housing Survey. Markets with higher rental costs experience shorter tenant occupancy; as higher rental costs may accelerate tenant switches into ownership. Duration of residence is increased in high-rise multifamily apartments, as indicated by the significant negative coefficient on the proportion of units in buildings with seven or more stories. ${ }^{10}$ As anticipated, duration of residence is significantly damped among renters of large single-family units (4-or-more bedrooms). Results also vary significantly among structure types, with increased residency duration in multifamily elevator buildings and the opposite in mobile rental homes. Consistent with the above discussion, a sizable and highly significant negative coefficient is attached to the multi-story (with elevator) multifamily structure type.

The duration of residence should reflect the mobility characteristics of the renter population, together with measures of change in the size of renter populations and the availability of below-market rental units. Population mobility is proxied directly by the percentage of population that moved in the prior year. Additional regressors include the percentage of elderly and poverty level households. The effects of lowerincome status on mobility are unclear a priori. While those households often experience relatively high rates of job change, their residential mobility may be adversely affected by transactions costs associated with household moves. Similarly, household move rates typically decline with age, as a variety of concerns,

\footnotetext{
${ }^{10}$ There is substantial variation across MSAs in the share of the rental housing stock that is in buildings with sevenor-more stories. The share averaged 7.1 percent over our sample, and varied from 0.4 percent in the Houston and Dallas-Fort Worth MSAs to 36.9 percent in the New York MSA.
} 
including health status, social, and family ties may limit the mobility of that group. As expected, Table IV indicates that more mobile households have a higher risk of turnover. Further, tenant turnover rises with the MSA percentage of poverty population. However, contrary to expectations, risk of tenant turnover rises with the percentages of elderly MSA populations. Results also indicate significantly higher risk of turnover in areas characterized by higher proportions of minority households. All things equal, duration of residence is increased in MSAs with higher proportions of central city rental housing stock.

It is further hypothesized that the duration of residence will increase in metropolitan areas with greater proportions of rent-controlled or public housing units. Those units typically are available at belowmarket rents that provide a disincentive for households occupying the units to move. As expected, estimation results indicate increased duration of residence in metropolitan areas characterized by a higher percentage of rent-controlled units. ${ }^{11}$ In contrast, greater proportions of public housing served to reduce duration of residence.

Population growth as derived from indigenous sources and from interregional migration should affect the duration of rental housing occupancy. On the one hand, unanticipated population increases may lead to lower levels of short-run rental unit vacancies and increased duration of residence; alternatively, areas characterized by relatively high rates of anticipated population growth may have a higher incidence of rental vacancies and a lower duration of residence. Our results are consistent with the former hypothesis, as a negative and significant coefficient is associated with the rate of MSA population growth. Similarly, we hypothesize that expansion in the stock of rental housing, as reflected in multifamily building permit issuance, may reflect a higher demand of rental housing in short run, hence result in reduced incidence of vacancy and increased duration of residence. Results indicate the anticipated negative and significant coefficient associated with the issuance of multifamily building permits. Finally, MSA-specific economic cycles are proxied by unemployment rates, which serve to indicate the occurrence and timing of local economic downturns. As is well appreciated, voluntary job switching is damped during a period of economic 
downturn. As expected, increases in MSA unemployment rates exert a negative and highly significant effect on hazard rate of residence duration.

As suggested above, the analysis further includes MSA-level fixed effects so as to account for locational deviations in the baseline survival function. For the most part, results here are highly significant, suggesting the appropriateness of estimation of MSA-specific hazard functions.

Table V reports predicted cumulative turnover rates for selected MSAs, based on the estimated model 2 evaluated at the sample means of the time-varying and time-invariant covariates. Panels $\mathrm{A}, \mathrm{B}$, and $\mathrm{C}$ present cumulative rental housing turnover rates at the end of $3^{\text {rd }}, 5^{\text {th }}$, and $10^{\text {th }}$ year for mobile home, single family detached houses, and multifamily elevator units in New York City, Los Angeles, and Dallas, respectively. The results show that cumulative turnover rates at the end of year 3 of the lease in Dallas were 17\% higher than in New York City, and about 11\% higher than in Los Angeles. Cumulative turnover rates for mobile home renters at the end of $3^{\text {rd }}$ year were about $8 \%$ higher than renters in multi-story multifamily units. Cumulative turnover rates for renters in single-family detached houses were about $4 \%$ higher than in multifamily units. Similar patterns persist over the time; however, the magnitudes of the estimated differences decline significantly by the end of $10^{\text {th }}$ year.

Table VI simulates the impacts of changes in housing policy and regional economics on rental housing turnover rates. The analysis indicates that on average, cumulative rental housing tenant turnover rates in New York City at the end of years 3, 5, and 10 would increase by about 1 percent if rent control was repealed. The simulation further indicates that NYC cumulative tenant turnover rates (by the end of year 3) would increase by 12 percent if rental housing were more geographically dispersed, as indicated by a reduction in the central city share of the rental stock to that of the national average level. Similarly, a decline in the density of NYC rental housing, as simulated in the reduction in the metropolitan share of buildings with seven or more stories to the national average level, would result in a 13 percent increase in the cumulative tenant turnover rates by the end of year 3 of lease. A simulated reduction to the national

\footnotetext{
${ }^{11}$ Rent controlled units comprised only 4.9 percent of rental units in the event-history sample. The states of
} California, Connecticut, New Jersey, New York, and the District of Columbia are the only areas that have MSAs 
average level in the percentage of NYC rental households in poverty would serve to reduce cumulative tenant turnover rates by about 4 percent. Finally, an adjustment in the NYC unemployment rate to national average levels would result in a modest $0.8 \%$ increase in cumulative tenant turnover rates by the end of year 10 .

\section{Conclusion}

Occupancy duration in rental housing has a wide distribution that is heavily skewed toward shorter durations: median duration is between one and two years, with some tenants staying in their homes well over a decade. Because tenant turnover is relatively high, analysis of duration of residence requires a similarly high-frequency data series. Further, hazard-rate models are especially applicable to duration analyses, but require a sufficiently long time-series to accurately model the underlying dynamics.

The data used in this paper, collected by the BLS for its CPI calculations, are uniquely well suited to the analysis of tenant occupancy duration. The data are high frequency (semi-annual), cover a long time series (12 years), span all structure types, and are national in scope. By applying innovative hazardrate estimation techniques, the resulting model identifies a variety of time-varying and time-invariant determinants of residency duration.

This paper provides new evidence as regards tenant and market characteristics that determine the

duration of residency. Results indicate that the duration of residence is highly time dependent, given significant intertemporal variation in many of the housing and market covariates. Research findings further reveal that median housing costs, public housing share of the rental stock, poverty rate, and African-American and Hispanic share of tenant households are among those factors that positively affect tenant turnover hazard rates and hence are negatively related to tenant residence duration. Elevator buildings, unemployment rate, population growth and central city share of the

with rent control. 
rental stock negatively affect tenant turnover hazard rates and hence are positively related with tenant residence duration. Further, the estimated pattern of duration of residence was shown to vary substantially across 33 large metropolitan markets.

The empirical analysis offers an improved understanding of tenant turnover, building occupancy, and rent flows critical to investment property valuation and development. In that regard, elevator highrises tend to attract longer-duration tenants, whereas the opposite is evidenced for garden apartments. Also, occupancy duration varies significantly across metropolitan areas, after controlling for important housing stock, tenant, and macroeconomic factors. In general, metropolitan areas in the Mid-West tend to have higher turnover among tenants than cities in other parts of the nation. The empirical analysis also sheds light on the duration implications of changes in the metropolitan geographic dispersion and density of rental housing. Findings for New York City indicate that increased dispersion of rental housing, as reflected in reduction in the share of rental stock in the central city to national average levels, would serve to boost cumulative tenant turnover rates by 12 percent by the end of year three of the rental lease. Similarly, simulated reduction in the density of rental housing, as reflected in downward adjustment in the share of NYC buildings with seven or more stories to national average levels, would serve to increase cumulative tenant turnover rates by 13 percent. 


\section{References}

Arnott, R. (1989), "Housing Vacancies, Thin Markets, and Idiosyncratic Tastes," Journal of Real Estate Finance and Economics, 2(1), 5-30.

Belkin, J., D. J. Hempel and D. McLeavey (1976), "An Empirical Study of Time on the Market Using Multidimensional Segmentation of Housing Markets," American Real Estate and Urban Economics Association Journal, 4(2), 57-76.

Belsky, E. and J. Goodman (1996), "Explaining the Vacancy Rate-Rent Paradox of the 1980s," Journal of Real Estate Research, 11(3): 309-23.

Blank, D. M. and L. Winnick (1953), "The Structure of the Housing Market," Quarterly Journal of Economics, 67 (2): 181-208.

Cox, D. R. (1972), "Regression Models and Life-Tables," Journal of the Royal Statistical Society Ser. B, $34,187-220$.

Cox, D. R. (1975), “Partial Likelihood,” Biometrika, 62, 269-279.

Cox, D. R. and D. Oakes (1984), Analysis of Survival Data, London: Chapman and Hall.

Deng, Y. (1995), "The Contingent Claims and Competing Risks for Mortgage Termination by Default and Prepayment," Ph.D. Dissertation, University of California at Berkeley.

Deng, Y. (1997), "Mortgage Termination: An Empirical Hazard Model with Stochastic Term Structure," Journal of Real Estate Finance and Economics, 14(3), 309-331.

Gabriel, S. A., and F. E. Nothaft (1988), "Rental Housing Markets and the Natural Vacancy Rate," American Real Estate and Urban Economics Association Journal, 16(4), 419-429.

Gabriel, S. A., and F. E. Nothaft (2001), "Rental Housing Markets, The Incidence and Duration of Vacancy, and the Natural Vacancy Rate," Journal of Urban Economics, 49(1), 121-49.

Gronberg, T. and W. Reed (1985), "Estimation of Duration Models Using the Annual Housing Survey," Journal of Urban Economics, 31(3), 311-324, 1992.17, 209-229.

Guasch, J. and R. Marshall (1987), "A Theoretical and Empirical Analysis of the Length of Residency Discount in the Rental Housing Market," Journal of Urban Economics, 22(3), 291-311.

Han, A. K., and J. A. Hausman (1990), "Flexible Parametric Estimation of Durationduration and Competing Risk Models," Journal of Applied Econometrics, 5(1), 1-28.

Härdle, W. (1990), “Applied Nonparametric Regression,” Cambridge University Press.

Haurin, D. (1988), “The Duration of Marketing Time of Residential Housing," American Real Estate and Urban Economics Association Journal, 16(4), 396-410.

Kluger, B. D., and N. G. Miller (1990), "Measuring Residential Real Estate Liquidity," American Real Estate and Urban Economics Association Journal, 18(2), 145-159.

Kalbfleisch, J. D., and R. L. Prentice (1980), The Statistical Analysis of Failure Time Data, New York: John Wiley.

Muller, R. (1991), "Rent Control and Vacancy Rates in Canada," QSEP Research Report No. 275, McMaster University, Canada.

Rosen, K., and L. Smith (1983), “The Price Adjustment Process and the Natural Vacancy Rate," American Economic Review, 73 (4): 779-86. 
Rosenthal, S. (1988), “A Residence Time Model of Housing Markets," Journal of Public Economics, 36(1), 87-109.

Ryu, K. (1994), "Group Duration Analysis of the Proportional Hazard Model: Minimum Chi-squared Estimators and Specification Tests," Journal of the American Statistical Association, 89(428), 13861397.

Sternberg, T. D. (1994), "The Duration of Rental Housing Vacancies," Journal of Urban Economics, 36(2), 143-160.

U.S. Department of Commerce, American Housing Survey for metropolitan areas, Current Housing Reports Series H170, various dates.

U.S. Department of Labor (1992), "The Consumer Price Index," Chapter 19, in BLS Handbook of Methods, Bulletin 2414.

Wheaton, W. and R. Torto (1994), “Office Rent Indices and Their Behavior over Time," Journal of Urban Economics, 35 (2): 121-139.

Zuehlke, T. W. (1987), "Duration Dependence in the Housing Market," Review of Economics and Statistics, 69(4), 701-704. 


\section{TABLE I. Tenant OCCUPANCY OF Less Than One Year By StRucture Type: AHS AND BLS COMPARISON}

\begin{tabular}{c|c|c|c}
\hline \hline \multicolumn{2}{c|}{ American Housing Survey: 1997} & \multicolumn{2}{c}{ Bureau of Labor Statistics: 1987-1998 } \\
\hline Structure Type & $\begin{array}{c}\text { Percent Moved } \\
\text { In Past Year }\end{array}$ & Structure Type & $\begin{array}{c}\text { Percent Occupied Less } \\
\text { Than One Year }\end{array}$ \\
\hline 1-unit detached & 32 & One-family detached & 45 \\
\hline 1-unit attached & 41 & One-family semi-attached & 46 \\
\hline 2 to 4 units & 35 & One-family attached & 46 \\
\hline 5 to 9 units & 41 & Multifamily: no elevator & 37 \\
\hline 10 to 19 units & 46 & Multifamily: with elevator & 46 \\
\hline 20 to 49 units & 35 & & 59 \\
\hline 50 units or more & 27 & Mobile home & 46 \\
\hline Mobile home & 40 & Other & 45 \\
\hline All rental units & 36 & All rental units & \\
\hline
\end{tabular}

Source: American Housing Survey for the United States 1997, Current Housing Reports H150/97, Table 41 , p. 178, and authors' calculations of BLS data.

\section{TABle II. Length of Tenant OCCUPANCy: DeCEnNial CENSUS AND BLS COMPARISON}

\begin{tabular}{c|c|c|c}
\hline \hline \multicolumn{2}{c|}{ Census of Population and Housing: 1990 } & Bureau of Labor Statistics: 1987-1998 \\
\hline Year Tenant Moved In & $\begin{array}{c}\text { Percent of Rental Housing } \\
\text { Stock }\end{array}$ & $\begin{array}{c}\text { Length of Tenant } \\
\text { Occupancy }\end{array}$ & $\begin{array}{c}\text { Percent of Rental } \\
\text { Housing Stock }\end{array}$ \\
\hline 1989-March 1990 & 42 & Less than 1 year & 45 \\
\hline $1985-1988$ & 35 & 1 to 5 years & 44 \\
\hline $1980-1984$ & 12 & 6 to 10 years & 10 \\
\hline Before 1980 & 12 & 10 years or more & 1 \\
\hline
\end{tabular}

Note: Columns may not sum to 100 because of rounding.

Source: 1990 Census of Population and Housing, Table H29 (http://homer.ssd.census.gov/cdrom/lookup), and authors' calculations of BLS data. 
TABLE III. Means and Standard DeVIations of Duration, SuRVival Rates, AND COVARIATES AT TERMINATION AND IN EVENT HISTORY SAMPLE

\begin{tabular}{|c|c|c|}
\hline Variable & At Termination & Event History \\
\hline $\begin{array}{l}\text { Duration of Occupancy } \\
\text { (measured semi-annually) }\end{array}$ & $\begin{array}{c}1.464 \\
(3.908)\end{array}$ & \\
\hline $\begin{array}{l}\text { Conditional Probability of } \\
\text { Continuing Occupancy }\end{array}$ & $\begin{array}{c}0.675 \\
(0.165)\end{array}$ & \\
\hline $\begin{array}{l}\text { Log Value of } \\
\text { Multifamily Building Permit }\end{array}$ & $\begin{array}{c}7.462 \\
(0.934)\end{array}$ & $\begin{array}{l}7.485 \\
(0.899)\end{array}$ \\
\hline $\begin{array}{l}\text { Unemployment Rate } \\
\text { (percent) }\end{array}$ & $\begin{array}{l}5.641 \\
(1.640)\end{array}$ & $\begin{array}{c}5.661 \\
(1.670)\end{array}$ \\
\hline $\begin{array}{l}\text { Population Growth } \\
\text { (percent) }\end{array}$ & $\begin{array}{c}0.005 \\
(0.005)\end{array}$ & $\begin{array}{c}0.005 \\
(0.005)\end{array}$ \\
\hline $\begin{array}{l}\text { Black and Hispanic Population } \\
\text { (percent) }\end{array}$ & $\begin{array}{c}0.262 \\
(0.121)\end{array}$ & $\begin{array}{c}0.260 \\
(0.123)\end{array}$ \\
\hline $\begin{array}{l}\text { Elder Population } \\
\text { (percent) }\end{array}$ & $\begin{array}{c}0.147 \\
(0.106)\end{array}$ & $\begin{array}{c}0.152 \\
(0.118)\end{array}$ \\
\hline $\begin{array}{l}\text { Recent Mover } \\
\text { (percent) }\end{array}$ & $\begin{array}{c}0.181 \\
(0.046)\end{array}$ & $\begin{array}{c}0.175 \\
(0.044)\end{array}$ \\
\hline $\begin{array}{l}\text { Poverty } \\
\text { (percent) }\end{array}$ & $\begin{array}{c}0.121 \\
(0.041)\end{array}$ & $\begin{array}{c}0.121 \\
(0.041)\end{array}$ \\
\hline $\begin{array}{l}4+\text { Bedrooms } \\
\text { (percent) }\end{array}$ & $\begin{array}{c}0.042 \\
(0.015)\end{array}$ & $\begin{array}{c}0.043 \\
(0.014)\end{array}$ \\
\hline $\begin{array}{l}7+\text { Stories } \\
\text { (percent) }\end{array}$ & $\begin{array}{c}0.063 \\
(0.081)\end{array}$ & $\begin{array}{c}0.071 \\
(0.088)\end{array}$ \\
\hline $\begin{array}{l}\text { Public Housing } \\
\text { (percent) }\end{array}$ & $\begin{array}{c}0.057 \\
(0.027)\end{array}$ & $\begin{array}{c}0.060 \\
(0.027)\end{array}$ \\
\hline $\begin{array}{l}\text { Rent Control } \\
\text { (percent) }\end{array}$ & $\begin{array}{c}0.043 \\
(0.075)\end{array}$ & $\begin{array}{c}0.049 \\
(0.080)\end{array}$ \\
\hline $\begin{array}{l}\text { Log Value of } \\
\text { Median Housing Cost }\end{array}$ & $\begin{array}{c}6.311 \\
(0.223)\end{array}$ & $\begin{array}{l}6.330 \\
(0.229)\end{array}$ \\
\hline $\begin{array}{l}\text { Central City } \\
\text { (percent) }\end{array}$ & $\begin{array}{c}0.432 \\
(0.176)\end{array}$ & $\begin{array}{c}0.439 \\
(0.179)\end{array}$ \\
\hline No. of Observations & 120,396 & 301,467 \\
\hline
\end{tabular}

Note: Standard deviations are in parentheses. 
TABLE IV. Estimates of Proportional HaZARD MOdEL OF RENTAL HOUSING OCCUPANCY TERMINATION

\begin{tabular}{|c|c|c|}
\hline & Model 1 & Model 2 \\
\hline $\begin{array}{l}\text { Black and Hispanic Population } \\
\text { (percent) }\end{array}$ & $\begin{array}{l}1.718 \\
(29.06)\end{array}$ & $\begin{array}{l}1.823 \\
(29.75)\end{array}$ \\
\hline $\begin{array}{l}4+\text { Bedrooms } \\
\text { (percent) }\end{array}$ & $\begin{array}{l}4.518 \\
(29.56)\end{array}$ & $\begin{array}{l}5.026 \\
(31.58)\end{array}$ \\
\hline $\begin{array}{l}7+\text { Stories } \\
\text { (percent) }\end{array}$ & $\begin{array}{l}-0.996 \\
(10.33)\end{array}$ & $\begin{array}{l}-1.144 \\
(11.33)\end{array}$ \\
\hline $\begin{array}{l}\text { Recent Mover } \\
\text { (percent) }\end{array}$ & $\begin{array}{l}2.044 \\
(20.37)\end{array}$ & $\begin{array}{l}2.310 \\
(22.11)\end{array}$ \\
\hline $\begin{array}{l}\text { Elder Population } \\
\text { (percent) }\end{array}$ & $\begin{array}{l}0.039 \\
(3.64)\end{array}$ & $\begin{array}{l}0.033 \\
(3.02)\end{array}$ \\
\hline $\begin{array}{l}\text { Poverty } \\
\text { (percent) }\end{array}$ & $\begin{array}{c}3.052 \\
(65.49)\end{array}$ & $\begin{array}{c}3.127 \\
(64.29)\end{array}$ \\
\hline $\begin{array}{l}\text { Central City } \\
\text { (percent) }\end{array}$ & $\begin{array}{l}-0.795 \\
(41.31)\end{array}$ & $\begin{array}{l}-0.841 \\
(42.84)\end{array}$ \\
\hline $\begin{array}{l}\text { Public Housing } \\
\text { (percent) }\end{array}$ & $\begin{array}{l}3.140 \\
(33.67)\end{array}$ & $\begin{array}{c}3.019 \\
(31.23)\end{array}$ \\
\hline $\begin{array}{l}\text { Rent Control } \\
\text { (percent) }\end{array}$ & $\begin{array}{l}-0.313 \\
(5.06)\end{array}$ & $\begin{array}{l}-0.155 \\
(2.38)\end{array}$ \\
\hline $\begin{array}{l}\text { Log Value of } \\
\text { Median Housing Cost }\end{array}$ & $\begin{array}{c}2.557 \\
(257.00)\end{array}$ & $\begin{array}{c}2.552 \\
(251.54)\end{array}$ \\
\hline $\begin{array}{l}\text { Log Value of } \\
\text { Building Permit }\end{array}$ & $\begin{array}{l}-0.023 \\
(15.09)\end{array}$ & $\begin{array}{l}-0.019 \\
(11.94)\end{array}$ \\
\hline $\begin{array}{l}\text { Unemployment Rate } \\
\text { (percent) }\end{array}$ & $\begin{array}{c}-0.081 \\
(111.43)\end{array}$ & $\begin{array}{c}-0.080 \\
(107.94)\end{array}$ \\
\hline $\begin{array}{l}\text { Population Growth } \\
\text { (percent) }\end{array}$ & $\begin{array}{r}-11.307 \\
(38.90)\end{array}$ & $\begin{array}{l}-10.913 \\
(36.56)\end{array}$ \\
\hline Single Family Detached & $\begin{array}{l}-0.067 \\
(5.03)\end{array}$ & $\begin{array}{l}-0.066 \\
(5.02)\end{array}$ \\
\hline Single Family Semi-Detached & $\begin{array}{l}-0.046 \\
(3.45)\end{array}$ & $\begin{array}{l}-0.046 \\
(3.43)\end{array}$ \\
\hline Single Family Attached & $\begin{array}{l}-0.042 \\
(3.15)\end{array}$ & $\begin{array}{l}-0.043 \\
(3.24)\end{array}$ \\
\hline Mobile Home & $\begin{array}{l}0.040 \\
(2.71)\end{array}$ & $\begin{array}{l}0.037 \\
(2.54)\end{array}$ \\
\hline Multifamily with Elevator & $\begin{array}{c}-0.192 \\
(14.43)\end{array}$ & $\begin{array}{c}-0.188 \\
(14.28)\end{array}$ \\
\hline Multifamily without Elevator & $\begin{array}{l}-0.036 \\
(2.69)\end{array}$ & $\begin{array}{l}-0.035 \\
(2.65)\end{array}$ \\
\hline
\end{tabular}


TABLE IV. ESTIMATES OF PROPORTIONAL HAZARD MODEL of RENTAl Housing OCCUPANCY TERMINATION (CONTINUEd)

\begin{tabular}{|c|c|c|}
\hline & Model 1 & Model 2 \\
\hline Atlanta & $\begin{array}{c}-0.635 \\
(54.51)\end{array}$ & \\
\hline Baltimore & $\begin{array}{c}-0.304 \\
(32.97)\end{array}$ & \\
\hline Boston & $\begin{array}{c}-0.853 \\
(51.59)\end{array}$ & \\
\hline Charlotte & $\begin{array}{c}-0.342 \\
(26.02)\end{array}$ & \\
\hline Chicago & $\begin{array}{c}-0.261 \\
(19.38)\end{array}$ & \\
\hline Cincinnati & $\begin{array}{c}0.358 \\
(24.91)\end{array}$ & \\
\hline Cleveland & $\begin{array}{c}0.248 \\
(16.05)\end{array}$ & \\
\hline Dallas & $\begin{array}{c}0.148 \\
(10.74)\end{array}$ & \\
\hline Denver & $\begin{array}{c}-0.025 \\
(1.89)\end{array}$ & \\
\hline Detroit & $\begin{array}{c}0.067 \\
(5.03)\end{array}$ & \\
\hline Hartford & $\begin{array}{l}-0.607 \\
(45.61)\end{array}$ & \\
\hline Houston & $\begin{array}{l}-0.065 \\
(5.05)\end{array}$ & \\
\hline Indianapolis & $\begin{array}{c}0.523 \\
(36.25)\end{array}$ & \\
\hline Kansas City & $\begin{array}{c}0.342 \\
(28.17)\end{array}$ & \\
\hline Los Angeles City & $\begin{array}{c}-0.934 \\
(49.10)\end{array}$ & \\
\hline Los Angeles metro (excludes city) & $\begin{array}{c}-0.952 \\
(65.30)\end{array}$ & \\
\hline Miami & $\begin{array}{c}-0.985 \\
(47.43)\end{array}$ & \\
\hline Milwaukee & $\begin{array}{l}-0.012 \\
(0.99)\end{array}$ & \\
\hline
\end{tabular}


TABLE IV. Estimates OF PROPORTIONAL HAZARD MODEL OF RENTAL HOUSING OCCUPANCY TERMINATION (CONTINUED)

\begin{tabular}{|c|c|c|}
\hline & Model 1 & Model 2 \\
\hline Minneapolis & $\begin{array}{l}0.057 \\
(3.23)\end{array}$ & \\
\hline New Jersey (northern metro areas) & $\begin{array}{l}-0.746 \\
(48.57)\end{array}$ & \\
\hline New Orleans & $\begin{array}{l}-0.024 \\
(2.41)\end{array}$ & \\
\hline New York City & $\begin{array}{l}-0.262 \\
(6.62)\end{array}$ & \\
\hline Norfolk & $\begin{array}{l}-0.365 \\
(27.05)\end{array}$ & \\
\hline Philadelphia & $\begin{array}{l}-0.371 \\
(29.77)\end{array}$ & \\
\hline Pittsburgh & $\begin{array}{c}0.529 \\
(29.17)\end{array}$ & \\
\hline Portland & $\begin{array}{l}0.042 \\
(2.56)\end{array}$ & \\
\hline St. Louis & $\begin{array}{c}0.296 \\
(25.77)\end{array}$ & \\
\hline San Diego & $\begin{array}{l}-0.611 \\
(41.26)\end{array}$ & \\
\hline San Francisco & $\begin{array}{c}-2.050 \\
(124.12)\end{array}$ & \\
\hline Seattle & $\begin{array}{l}-0.042 \\
(2.63)\end{array}$ & \\
\hline Tampa & $\begin{array}{c}0.153 \\
(11.87)\end{array}$ & \\
\hline Washington & $\begin{array}{l}-0.955 \\
(57.20)\end{array}$ & \\
\hline R-Square & 0.6314 & 0.6399 \\
\hline
\end{tabular}

Note: T-ratios are in parentheses. A positive coefficient indicates the covariate is positively associated with rental housing turnover hazard rate, hence negatively associated to the rental housing occupancy duration. The number of observations in each model is 301,467 . Model 1 is specified with a common baseline hazard function. Model 2 is specified with MSA-specific baseline hazard functions. 
TABle V. Predicted Cumulative Rental Housing Tenant Turnover Rates

\begin{tabular}{l|ccc}
\hline \hline & \multicolumn{3}{|c}{ Cumulative Turnover Rates } \\
\hline & End of $3^{\text {rd }}$ Year & End of $5^{\text {th }}$ Year & End of $10^{\text {th }}$ Year \\
\hline New York City & & & \\
Mobile Home/Trailer & $58.63 \%$ & $75.09 \%$ & $96.47 \%$ \\
Single Family Detached & $54.88 \%$ & $71.44 \%$ & $95.10 \%$ \\
Multifamily with Elevator & $50.56 \%$ & $67.02 \%$ & $93.07 \%$ \\
\hline Los Angeles & & & $97.91 \%$ \\
Mobile Home/Trailer & $65.19 \%$ & $82.36 \%$ & $96.94 \%$ \\
Single Family Detached & $61.39 \%$ & $79.08 \%$ & $95.44 \%$ \\
Multifamily with Elevator & $56.92 \%$ & $74.96 \%$ & \\
\hline Dallas & & & $99.14 \%$ \\
Mobile Home/Trailer & $75.85 \%$ & $88.57 \%$ & $98.63 \%$ \\
Single Family Detached & $72.23 \%$ & $85.86 \%$ & $97.75 \%$ \\
Multifamily with Elevator & $67.82 \%$ & $82.29 \%$ & \\
\hline
\end{tabular}

Note: The predicted cumulative turnover rates are computed based on estimated model 2 reported in Table IV evaluated at the sample means of time-varying and time-invariant covariates at the MSA level. 


\section{TABLE VI. IMPACTS OF ChANGeS IN Housing Policy oR Regional ECONOMY on Predicted Cumulative Rental Housing Tenant Turnover Rates (NEW YORK CITY)}

\begin{tabular}{|c|c|c|c|}
\hline & \multicolumn{3}{|c|}{ Change in Cumulative Turnover Rates } \\
\hline & End of $3^{\text {rd }}$ Year & End of $5^{\text {th }}$ Year & End of $10^{\text {th }}$ Year \\
\hline \multicolumn{4}{|l|}{ No Rent Control } \\
\hline Mobile Home/Trailer & $0.99 \%$ & $1.02 \%$ & $1.04 \%$ \\
\hline Single Family Detached & $0.97 \%$ & $1.02 \%$ & $1.05 \%$ \\
\hline Multifamily with Elevator & $0.94 \%$ & $1.00 \%$ & $1.05 \%$ \\
\hline \multicolumn{4}{|c|}{ Central City \% Reduced to National Average Level } \\
\hline Mobile Home/Trailer & $11.75 \%$ & $11.55 \%$ & $11.19 \%$ \\
\hline Single Family Detached & $11.74 \%$ & $11.72 \%$ & $11.51 \%$ \\
\hline Multifamily with Elevator & $11.57 \%$ & $11.74 \%$ & $11.71 \%$ \\
\hline \multicolumn{4}{|c|}{ Poverty \% Reduced to National Average Level } \\
\hline Mobile Home/Trailer & $-3.75 \%$ & $-3.76 \%$ & $-3.71 \%$ \\
\hline Single Family Detached & $-3.67 \%$ & $-3.73 \%$ & $-3.72 \%$ \\
\hline Multifamily with Elevator & $-3.55 \%$ & $-3.65 \%$ & $-3.68 \%$ \\
\hline \multicolumn{4}{|c|}{ Unemployment Rate Adjusted to National Level } \\
\hline Mobile Home/Trailer & $-0.06 \%$ & $0.41 \%$ & $0.83 \%$ \\
\hline Single Family Detached & $-0.06 \%$ & $0.40 \%$ & $0.83 \%$ \\
\hline Multifamily with Elevator & $-0.06 \%$ & $0.40 \%$ & $0.83 \%$ \\
\hline \multicolumn{4}{|c|}{$7+$ Stories \% Reduced to National Average Level } \\
\hline Mobile Home/Trailer & $12.50 \%$ & $12.27 \%$ & $11.86 \%$ \\
\hline Single Family Detached & $12.50 \%$ & $12.46 \%$ & $12.22 \%$ \\
\hline Multifamily with Elevator & $12.34 \%$ & $12.50 \%$ & $12.45 \%$ \\
\hline
\end{tabular}

Note: Difference in predicted cumulative turnover rates are computed based on estimated model 2 reported in Table IV evaluated at the sample means of time-varying and time-invariant covariates for New York City, excepted for the control variable specified in each panel that was replaced by national average level or otherwise specified level. 
EXHIBIT I. DISTRIBUTION OF RENTAL HOUSING OCCUPANCY DURATION

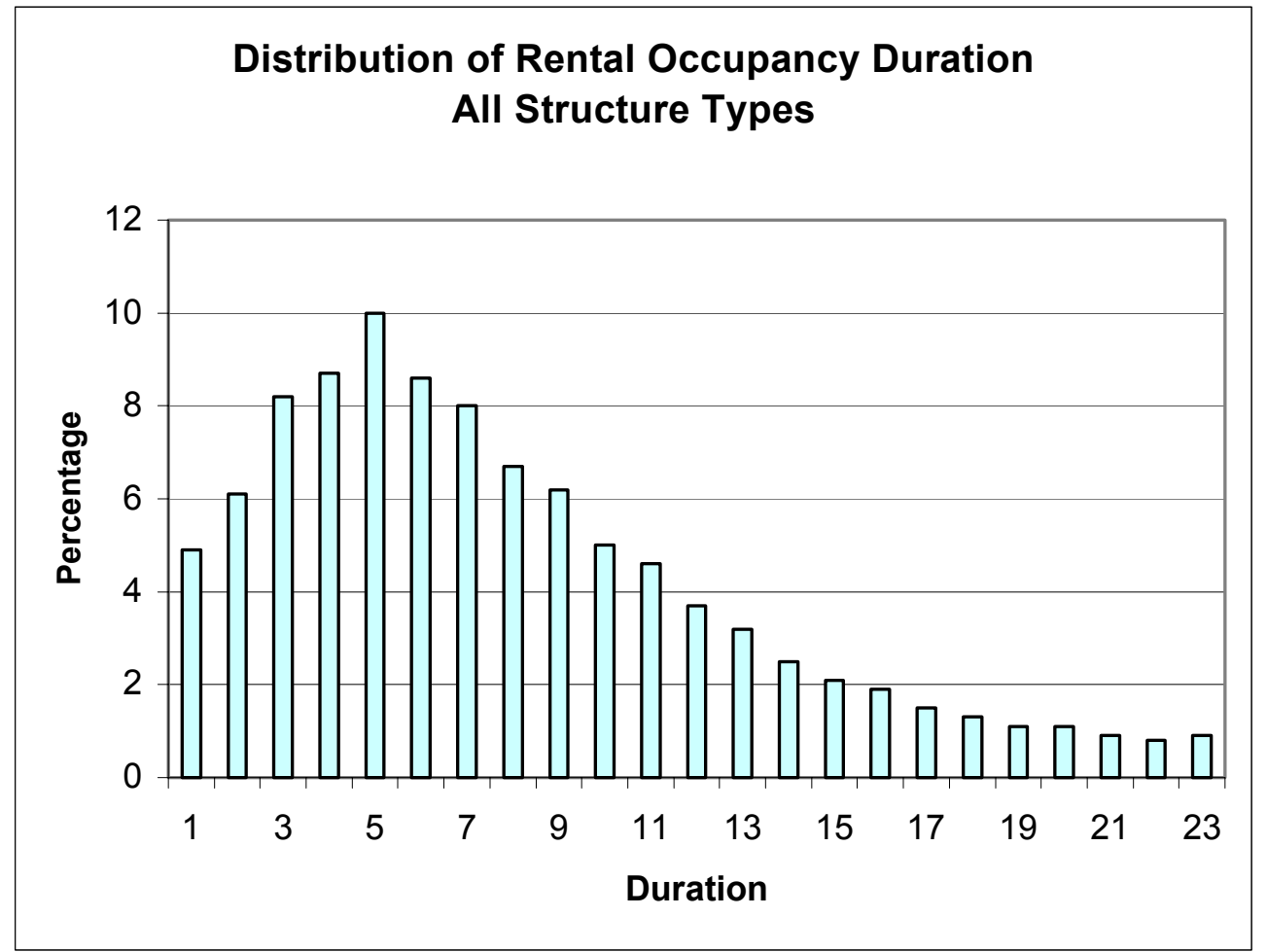


EXHIBIT II. DisTRIBUTION OF RENTAL HOUSING OCCUPANCY DURATION BY BUILDING STRUCTURE TYPES
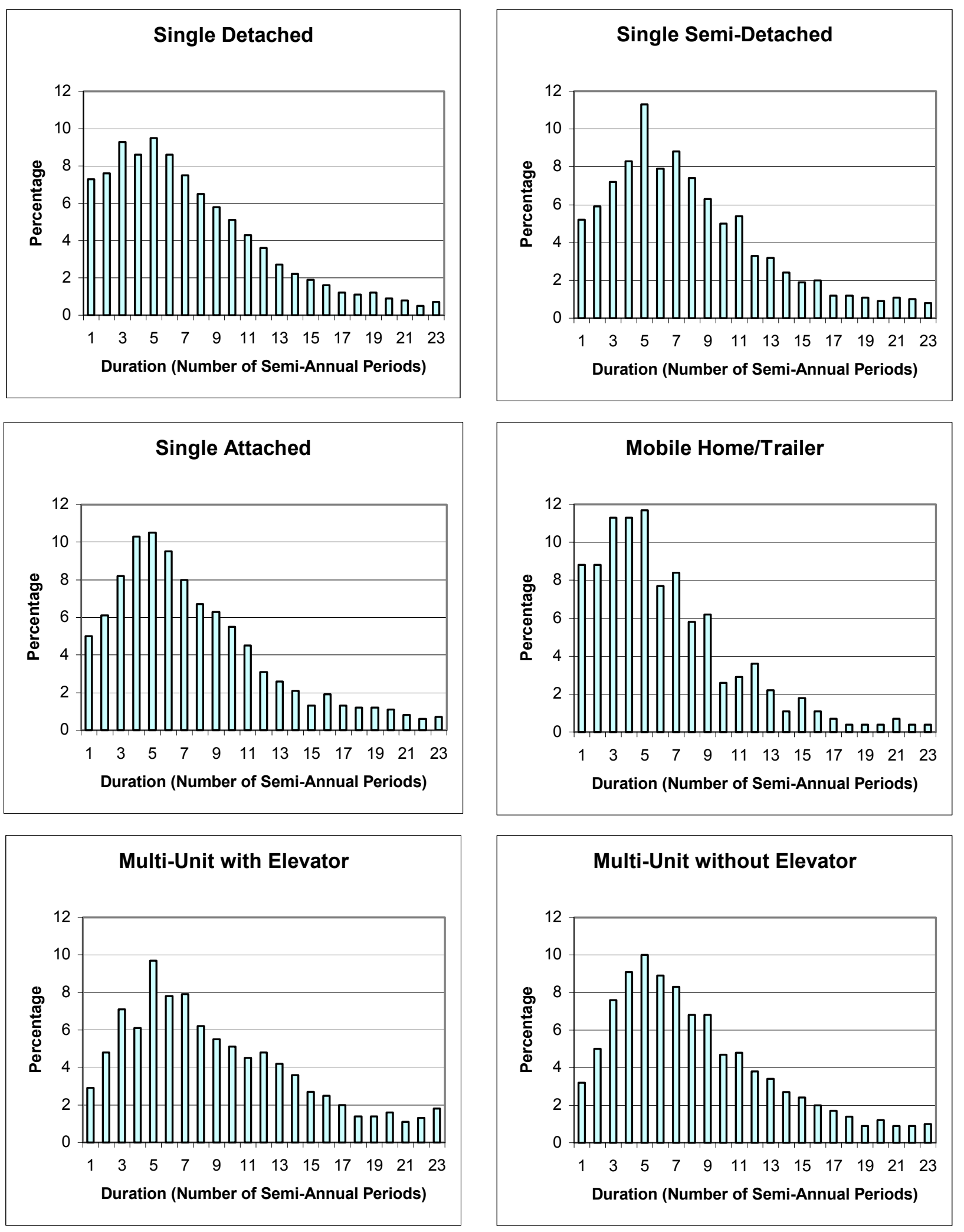
EXHIBIT III. DistRIBUTION OF RENTAL HOUSING OCCUPANCY DURATION BY MSAS
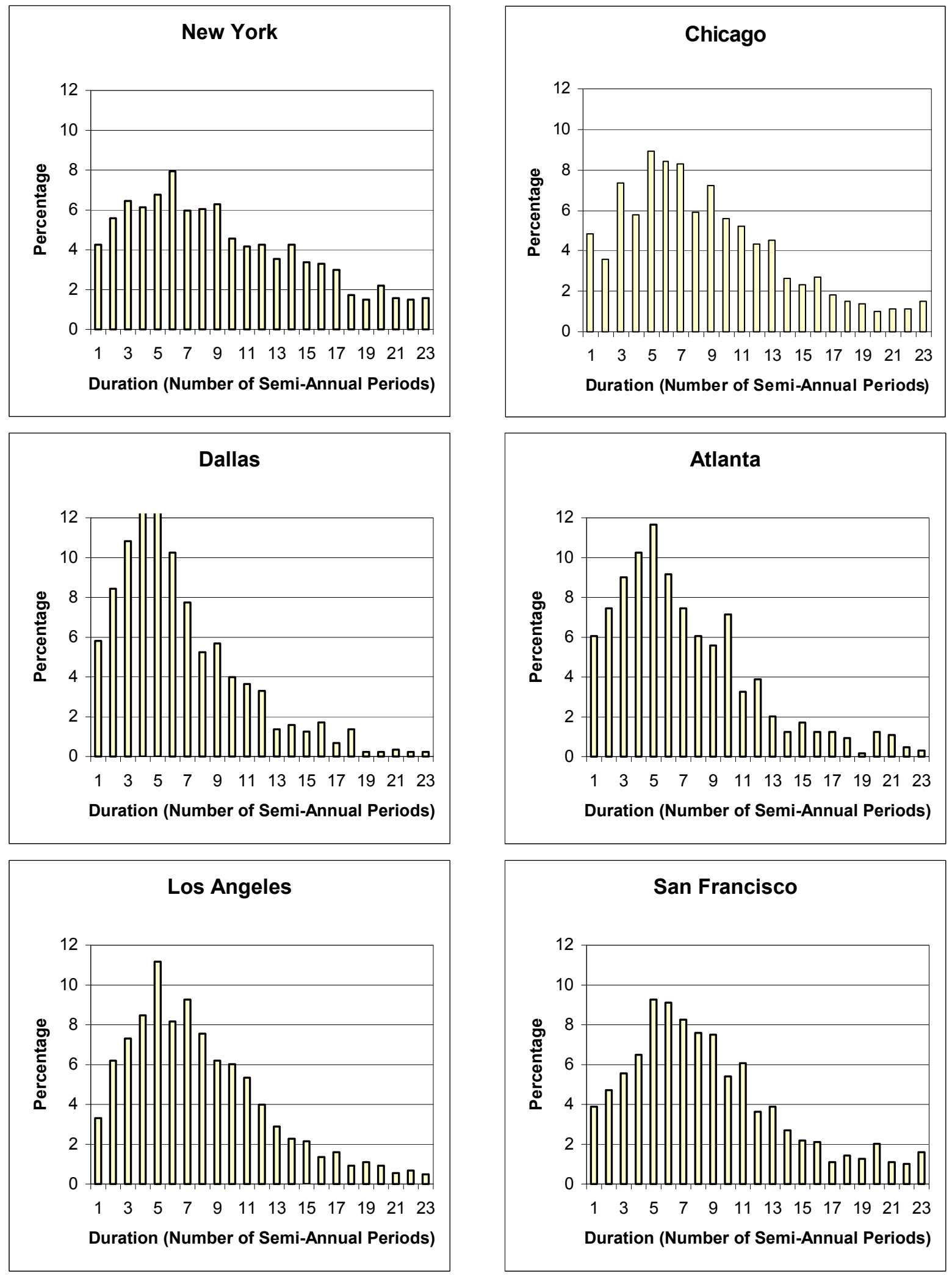